\title{
Isolation of Cellulolytic Lactic-Acid Bacteria from Mentok (Anas moschata) Gastro-Intestinal Tract
}

\author{
H. Herdian ${ }^{a, *}$, L. Istiqomah ${ }^{a}$, E. Damayantia ${ }^{a}$ A.E. Suryani ${ }^{a}$, A.S. Anggraeni ${ }^{a}$, N. Rosyada ${ }^{b}$, \& A. Susilowati ${ }^{b}$ \\ aResearch Centre For Natural Product Technology (BPTBA) \\ Indonesian Institute of Sciences (LIPI) \\ Jalan Yogya Wonosari Km 33.5 Playen, Gunungkidul, D.I.Yogyakarta 55861 Indonesia \\ 'Biology Study Program, Faculty of Math and Natural Sciences, \\ Sebelas Maret University, Surakarta, Central Java, Indonesia \\ *Corresponding author: hendravit@yahoo.com \\ (Received 26-04-2018; Reviewed 08-08-2018; Accepted 10-09-2018)
}

\begin{abstract}
Mentok, a local Indonesian name's of muscovy duck (Anas moschata), has been known as a duck with the capability to consume poor quality feed, high with non-starch carbohydrate (NSP) content. This capacity occurs because of the presence of microbial fermentation activity in the gastro intestinal tract (GIT) of mentok. However, the information about the identification and characterization of the cellulolytic microbes involved is limited. This study was expected to provide scientific contributions about gastrointestinal microbes, especially Lactic Acid Bacteria (LAB), with cellulolytic activities. The experiment was conducted to select LAB with cellulolytic activity from the GIT of mentok. Twenty six of selected LABs were isolated from the duodenum, cecum, and colon regions after microbiological characterization, i.e., morphology, catalase test, gas production, Gram staining, and motility test. Characterization for cellulolytic activity was analyzed by measuring the clearing zone on Carboxymethylcellulose (CMC) media, cell growth analysis on 1\% CMC as a carbon source, and CMCase value. Pediococcus acidilactici MK 20 isolate from colon region was selected LAB with the highest cellulolytic activity with the clearing zone diameter, and the CMCase value of $2.33 \mathrm{~mm}$ and $0.0153 \mathrm{U} / \mathrm{mL}$, respectively. Molecular identification using 16S rRNA gene sequences analysis revealed that $P$. acidilactici MK 20 isolate has $99 \%$ similarity with $P$. acidilactici strain ZW001. It was concluded that $P$. acidilactici MK 20 isolated from the colon part of the gastrointestinal tract of mentok, the Indonesian muscovy duck ( $A$. moschata) had cellulolytic activity.
\end{abstract}

Keywords: lactic acid bacteria, mentok, muscovy duck (Anas moschata), cellulolytic bacteria

\section{INTRODUCTION}

The existence of Non-Starch polysaccharide (NSP) on feed diet of monogastric animals especially on poultry ration tends to be a factor that produce an antinutritive-value effect on feed digestion system at the gastrointestinal tract (GIT). The physicochemical properties of NSP contribute to the binding impact of water constituent with the material in the gut that produces a higher viscosity of the digesta decreasing the rate of digestibility (Bedford, 2000). In addition, the coating processes of materials on the surface of the feed could inhibit the enzymatic reaction produced in the GIT (Căpriță et al., 2010). Cellulose has been classified as one of the NSP group (Bedford, 2000; Căpriță et al., 2010) known as a polysaccharide constructed from glucose monomer binding with a $1,4 \beta$ glycoside bond. The monogastric animal does not have a specific site on their intestinal-tract organs to accommodate the massive microflora ecosystem that leads to the degradation of the cellulose (Fonty \& Gouet, 1989). Some research groups have shown the degradation of cellulose by enzymatic action on poultry diets. The addition of cellulase from Trichoderma reesei and xylanase from a hyperproducing transgenic microorganism could decrease the viscosity of the digesta, increase sugar reduction level, and decrease $\mathrm{pH}$ (Boros et al., 1998). The addition of 1,3-1,4 $\beta$-glucanase $16 \mathrm{~A}$, and $1,4-\beta$ glucanase $8 \mathrm{~A}$ showed the decrease in the viscosity of the purified 1,3-1,4 $\beta$-glucan solution and increase in the nutritive value of barleybased poultry diet (Fernandes et al., 2016). Meantime, the addition of exogenous NSP enzyme on broiler-chicken pasture during winter season improved the broiler performance since the chicken could use the NSP forage grown at that season as energy sources (Buchanan et al., 2005).

Mentok, as an Indonesian name's of muscovy duck (Anas moschata), has been studied for many years by some research groups to capture the information about their performances abilities as a meat producing animal (Tugiyanti et al., 2013; Ali et al., 2014; Suci et al., 2017). In Indonesia, muscovy duck is well known as one of three local ducks breeds that produces meat (CIVAS, 2006). For the duck, some carbohydrate fractions, such 
as dietary fibre (DF) was used as one composition in feed. Józefiak et al. (2004) states that some carbohydrate fractions are not hydrolyzed by avian gastrointestinal enzymes but are fermented by the resident anaerobic microflora. Apajalahti (2015) reports that fermentation activities of bacteria at the GIT of the monogastric animals are concentrated in the cecum and colon. This condition contributes for the higher accumulation of short-chain fatty acids (SCFA) in the cecum compared with the other areas of the avian gastrointestinal tract (Józefiak et al., 2004). In the other studies, several specieses of lactic acid bacteria with probiotic properties were isolated from intestinal content of muscovy duck in Fujian Province, China (Xie et al., 2015) and in our previous study, meat quality and poultry performance were improved with LAB administration as probiotic (Istiqomah et al., 2013; Sofyan et al., 2012).

Over the last decade, the investigation on the identification, characterization, and utilization of microbes isolated from GIT of chicken increased rapidly. Some of them reported the use of lactic acid bacteria as a probiotic agent for chicken (Musikasang et al., 2009; Damayanti et al., 2014; Jannah et al., 2017; Hamida et al., 2015; Yeh et al., 2017; Julendra et al., 2017). Meanwhile, the information about the lactic acid bacteria isolated from the GIT of Indonesian ducks for poultry probiotic agent is still limited.

Regarding the concern of cellulolytic activity in poultry-animal digestive system, a study was conducted to isolate and characterize cellulolytic activity of Lactic Acid Bacteria isolated from GIT of mentok, Indonesian muscovy duck (Anas moschata). This study was expected to provide scientific contributions in the field of gastrointestinal microbes, especially BAL with cellulolytic activity.

\section{MATERIALS AND METHODS}

\section{Isolation and Identification of Lactic Acid Bacteria}

Lactic acid bacteria (LAB) were isolated from mentok (muscovy duck) by using the protocol used by Torshizi et al. (2008). Five grams of lumen samples from intestine, cecum, and colon were suspended in $0.85 \% \mathrm{NaCl}$ solution (Merck) and made up to $10^{10}$ serial dilutions. One hundred $\mu \mathrm{L}$ of each serial dilution was spred on a plate covered with de Man Rogosa Sharpe (MRS) agar medium (Oxoid) supplemented with $\mathrm{CaCO}_{3}$ $(0.2 \%, \mathrm{v} / \mathrm{v})$ in duplicate then incubated at $37^{\circ} \mathrm{C}$ for 24 $h$ in the anaerobic chamber with Anaerocult $\mathrm{CO}_{2}$ generator (Merck). The LAB colonies were detected by the existence of clearing zone. The parameters measured to identify Lactic acid bacteria consisted of morphology, catalase test, gas production, Gram staining, and motility test (Krieg et al., 2010).

\section{Cellulolytic Activity Assay of The Selected Lactic Acid Bacteria}

Preliminary screening of LAB isolates with cellulolytic activity was conducted by inoculating $10 \mu \mathrm{L}$ of LAB on paper disk on Agar plate sterile medium containing 1\% Carboxymethylcellulose (CMC). The composition of agar plate medium consisted of $1 \mathrm{~g}$ of $\mathrm{CMC}, 0.02 \mathrm{~g}$ of $\mathrm{MgSO}_{4} 7 \mathrm{H}_{2} \mathrm{O}, 0.075 \mathrm{~g}$ of $\mathrm{KNO}, 0.05 \mathrm{~g}$ of $\mathrm{K}_{2} \mathrm{HPO}_{4}, 0.002 \mathrm{~g}$ of $\mathrm{FeSO}_{4} 7 \mathrm{H}_{2} \mathrm{O}, 0.004 \mathrm{~g}$ of $\mathrm{CaCl}_{2} 2 \mathrm{H}_{2} \mathrm{O}$, $0.2 \mathrm{~g}$ of yeast extract, $1.5 \mathrm{~g}$ of agar, and $0.1 \mathrm{~g}$ of glucose diluted in $100 \mathrm{~mL}$ of distilled water. The experiment used three replicates paper disks for each $\mathrm{LAB}$ isolate and incubated at $37^{\circ} \mathrm{C}$ for $48 \mathrm{~h}$ in anaerobic condition. After incubation, the plates were flooded with Congo red $(1 \%, v / w)$ for $20 \mathrm{~min}$ then followed by destaining with $1 \mathrm{M} \mathrm{NaCl}$ for $20 \mathrm{~min}$. The $\mathrm{LAB}$ isolates strain with the largest clearing zone indicating the highest cellulolytic activity. Cellulolytic activity was measured by determining the cellulolytic index which was the ratio between the diameters of a clearing zone with a diameter of colonies (Meryandini et al., 2009; Setyati \& Subagiyo, 2012).

\section{Cell Density Analysis}

The analysis of cell density of LAB was performed to determine the ability of the LAB to consume cellulose by using Optical density (OD) as a growth parameter. The method of measuring referred to the procedure used by Rahayu et al. (2014) with a minor modification. One percent of the selected LAB culture $\left(10^{8} \mathrm{CFU} / \mathrm{mL}\right)$ was inoculated into $20 \mathrm{~mL}$ of sterile CMC Broth medium (consisted of $1 \mathrm{~g}$ of CMC, $0.02 \mathrm{~g}$ of $\mathrm{MgSO}_{4} 7 \mathrm{H}_{2} \mathrm{O}, 0.075$ $\mathrm{g}$ of $\mathrm{KNO} ; 0.05 \mathrm{~g}$ of $\mathrm{K}_{2} \mathrm{HPO} 4,0.002 \mathrm{~g}$ of $\mathrm{FeSO}_{4} 7 \mathrm{H}_{2} \mathrm{O}$, $0.004 \mathrm{~g}$ of $\mathrm{CaCl}_{2} 2 \mathrm{H}_{2} \mathrm{O}, 0.2 \mathrm{~g}$ of yeast extract, and $0.1 \mathrm{~g}$ of glucose and diluted in $100 \mathrm{~mL}$ of distilled water) and then incubated at $30^{\circ} \mathrm{C}$ for $24 \mathrm{~h}$. The treatments were performed using three replicates. Two hundred $\mathrm{mL}$ of sample from each treatment was placed on microplate consisted of 96 wells. The OD was measured at $620 \mathrm{~nm}$ of wavelength using microplate reader at 0,24 , and $48 \mathrm{~h}$ of incubation.

\section{Carboxymethyl Cellulase Activity Assay}

Carboxymethylcellulose activity (CMCase) was measured using Dinitrosalisic acid reagent (DNS) based on the estimated amount of reducing sugar released from $1 \%$ CMC diluted in $0.05 \mathrm{M}$ citric buffer at a $\mathrm{pH}$ of 4.8. A reaction medium containing $0.5 \mathrm{~mL}$ of $\mathrm{CMC}$ substrate dissolved in citrate buffer (acidity of 4.8) and $0.5 \mathrm{~mL}$ of enzymatic crude extract from cell-free supernatant of $\mathrm{LAB}$ culture and incubated at $50^{\circ} \mathrm{C}$ for $30 \mathrm{~min}$. The reaction was terminated by adding $1.5 \mathrm{~mL}$ of the DNS reagent and boiled in the water bath at $100^{\circ} \mathrm{C}$ for 5 min, cooled at room temperature, and then added $10 \mathrm{~mL}$ of distilled water. For each LAB isolate, three replicates were performed in this experiment. The quantity of sugar released was determined by measuring at a wavelength of $540 \mathrm{~nm}$ and Critical enzyme concentration (IU) $=0.185 \times$ CMC (sugar reduction) (mg) (Ghose, 1987).

\section{Molecular Identification of Lactic Acid Bacteria}

Lactic acid bacterial identification was performed molecularly by amplifying the $16 \mathrm{~S}$ ribosomal DNA (16S rDNA) sequence region. Amplification of $16 \mathrm{~S}$ rDNA 
area of bacteria was performed using PCR colony method. PCR 16S rDNA amplification per reaction of $30 \mu \mathrm{L}$ using primer 27F (5'-AGAGTTTGATCCTGGCTCAG-3 ') and 1492R primer (5'-GGTTACCTTGTTACGACTT-3') (Gong et al., 2007). The composition of the PCR reaction consisted of $15 \mu \mathrm{L}$ of Go Tag Green Master Mix 2x (Promega, 2016), $2.4 \mu \mathrm{L}$ of primer 27F (5'-AGAGTTTGATCCTGGCTCAG-3 ') $10 \mu \mathrm{M}, 2.4 \mu \mathrm{L}$ of primary 1492R (5' -GGTTACCTTGTTACGACTT-3 ') $10 \mu \mathrm{M}, 1 \mu \mathrm{L}$ of DNA template, and $9.2 \mu \mathrm{L}$ of ultrapure water DNA/RNase free. The PCR reaction used a PCR (Eppendorf German) machine with a first pre-denaturation at $94^{\circ} \mathrm{C}$ for $90 \mathrm{~s}$, followed by 30 cycles consisted of denaturation at $95^{\circ} \mathrm{C}$ for $30 \mathrm{~s}$, primer adherence at $50^{\circ} \mathrm{C}$ for $30 \mathrm{~s}$, and extension at $72^{\circ} \mathrm{C}$ for $90 \mathrm{~s}$. After 30 cycles were completed, the processed was continued with elongation phase at $72^{\circ} \mathrm{C}$ for $5 \mathrm{~min}$ and cooling at $4^{\circ} \mathrm{C}$ for $20 \mathrm{~min}$ (Promega, 2016).

The PCR product was further purified and cycled sequenced with the same primer Sequence analysis conducted in the laboratory of First Base (Malaysia). The next sequenced data were trimmed and assembled with BioEdit program and then converted in FASTA format. The DNA sequencing results in the following FASTA format at Basic Local Alignment Search Tool - Nuclotide (BLASTN) to locate the homology online at the DNA database center at National Center for Biotechnology Information (NCBI) (https://www.ncbi.nlm.nih.gov/). Phylogenetic analysis was performed by NeighborJoining tree method using ClustalX2 and MEGA5 programs. Grouping stability was calculated using 1000 bootstrap value (Cobos et al., 2011).

\section{Scanning Electron Microscope Analysis}

Morphological characteristics of strain $P$. acidilactici MK20 were observed using scanning electron microscope (SEM) after incubation at $37^{\circ} \mathrm{C}$ for $18 \mathrm{~h}$ on MRSB medium. After incubation, one loop of LAB single colony was added evenly on the surface of the carbon-tape covered stub. The sample was air dried and coated with $\mathrm{Au}$ (using $\mathrm{Au}$ ion sputter-Hitachi MC1000) with a setting of $10 \mathrm{~mA}$ for $60 \mathrm{~s}$ and observed using SEM Hitachi SU3500. The SEM setting of high vacuum mode, accelerating voltage of $5 \mathrm{kV}$, spot intensity of $30 \%$, and magnification of $10,000 \mathrm{x}$.

\section{Statistical Method}

The results of OD and glucose concentration measurement at $48 \mathrm{~h}$ observation was analyzed by one-way ANOVA with completely randomized design followed by Least Significant Difference method for testing the difference between treatments (Gomez \& Gomez, 1984). The statistical-analyses process was carried out by CoStat version 6.400 Program from CoHort Software with the one-way completely randomized and LSD for Means Test procedures. Graphic presentation was made by Microsoft Excel version 2010 from Microsoft Software.

\section{RESULTS}

\section{Isolation and Identification of Lactic Acid Bacteria}

There were 26 of LAB samples isolated from mentok GIT i.e., 7 taken from the duodenum, 6 from cecum, and 13 from colon region. The shapes of the LAB isolates appeared as cocci and rod morphologies. All of the LAB isolates were observed as negative catalase, nonmotile, Grampositive, and non-gas producer. The characterizations of the five selected LAB isolates with the highest cellulolytic activity are presented in Table 1.

\section{Cellulolytic Activity of Lactic Acid Bacteria}

Preliminary results of the screening cellulolytic assay showed that all of LAB isolates produced clear zones on CMC agar plate media after Congo red staining around the colony with diameter ranged from 0.23 to $3.22 \mathrm{~cm}$ (Table 1). Five isolates with the highest clear zone were MU $4(2.31 \mathrm{~cm})$, MS $14(2.40 \mathrm{~cm})$, MK $20(2.33$ $\mathrm{cm})$, MK $27(1.67 \mathrm{~cm})$, and MK $44(3.22 \mathrm{~cm})$ and these isolates were selected to proceed with growth assay and glucose concentration productivity assays. The observations of cell densities on $1 \%$ of $\mathrm{CMC}$ medium at $37^{\circ} \mathrm{C}$ for $48 \mathrm{~h}$ incubation were shown in Figure 1 . After a 48 -h incubation period, the results of the measurements of OD, glucose concentration, and CMCase were shown in Table 2. The highest values for OD and CMCase were 0.3398 , and $0.0153 \mathrm{U} / \mathrm{mL}$, respectively, that were obtained from MK 20 isolates derived from the mentok's colon.

Table 1. Characterization of lactic acid bacteria isolated from Muscovy duck gastrointestinal tract (GIT) and cellulolytic activity on $1 \% \mathrm{CMC}$ agar plate with Congo-red staining

\begin{tabular}{ccccccc}
\hline & & \multicolumn{5}{c}{ Assays } \\
\cline { 3 - 6 } Isolate code & Morphology & Gram Staining & Catalase & Motility & $\begin{array}{c}\text { Gas } \\
\text { production }\end{array}$ & $\begin{array}{c}\text { Clearing zone } \\
\text { diameter }(\mathrm{cm})\end{array}$ \\
\hline MU 4 & Long rod & + & - & - & - & 2.31 \\
MS 14 & Cocci & + & - & - & - & 2.40 \\
MK 20 & Cocci & + & - & - & - & 2.33 \\
MK 27 & Cocci & + & - & - & - & 1.67 \\
MK 44 & Cocci & + & - & - & - & 3.22 \\
\hline
\end{tabular}

Note: "+" (positive) = observed; “_" (negative) = not observed; MU = LAB isolated from duodenum; MS = LAB isolated from cecum; MK= LAB isolated from colon of Mentok. 


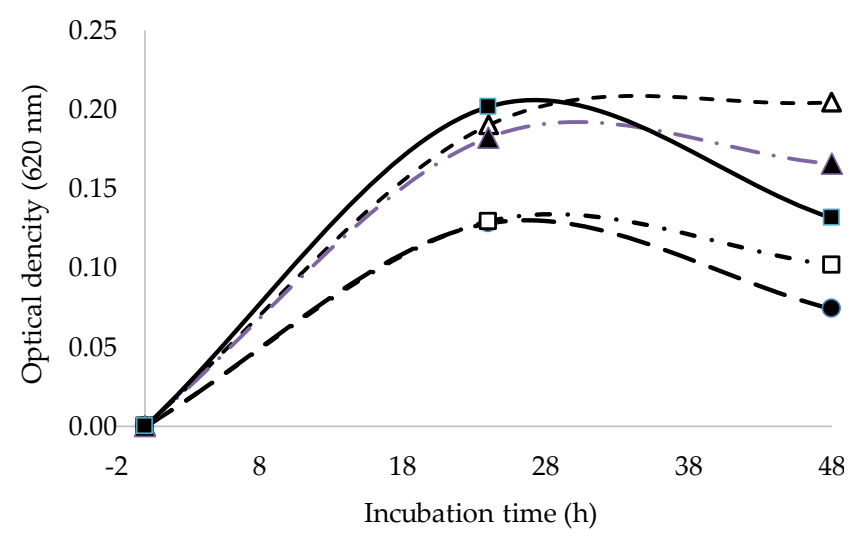

Figure 1. Cell density of lactic acid bacteria isolated from Muscovy duck gastrointestinal tract on $1 \%$ CMC medium at $37^{\circ} \mathrm{C}$ for $48 \mathrm{~h}$ incubation. MU $4(-\bullet-)=\mathrm{LAB}$ isolated from duodenum; MS $14(-\square-)=$ LAB isolated from cecum; and MK $20(-\Delta-)$, MK 27 (- $\boldsymbol{\Delta}-)$, MK 44 $(-\square-)=$ LAB isolated from colon.

\section{Molecular Identification of Selected Lactic Acid Bacteria}

The MK 20 isolate was identified as Pediococcus acidilactici. Homology BLAST sequence 16S rDNA MK 20 isolate with a length of $1428 \mathrm{bp}$ in DNA database (https://blast.ncbi.nlm.nih.gov/Blast.cgi, was accesed on on 12 March 2018) had max identity of $99 \%$, max score of 2627 , total score of $2627,100 \%$ of query coverage, E value of 0,0 against the nearby bacterial taxon $P$. acidilactici strain ZW001 (JN255181). Classification of the bacteria is Kingdom: Bacteria, Division: Firmicutes, Class: Bacilli, Order: Lactobacillales, Family: Lactobacillaceae, Genus: Pediococcus, Species: P. acidilactici. Phylogenetic tree of the MK 20 isolate was presented in Figure 2. Morphological characteristics of $P$. acidilactici MK20 using Scanning Electron Microscope (SEM) were shown in Figure 3.

\section{DISCUSSION}

\section{Isolation and Identification of Lactic Acid Bacteria}

In this result, we found that the cocci LAB was found dominant in isolates from cecum and colon. This result was different from that reported by Musikasang et al. (2009) that the proportion of rod and cocci of LAB isolated from the GIT of chicken were $85 \%$ and $15 \%$, respectively. In the other study, Xie et al. (2015) founded 4 rod selected LAB among 6 LAB from intestinal content of muscovy duck. Based on cellulolytic activity assay on CMC agar plate media, the clear zone appearance indicated that LAB colonies had the ability to degrade cellulose. The highest clear zone diameter of a LAB in this study was revealed by MK 44 isolate from colon region $(3.22 \mathrm{~cm})$. This result was lower than Bacillus pumilus, Klebsiella spp. $(5.0-7.0 \mathrm{~cm})$ but it was higher than Stenotrophomonas spp., Enterococcus casseliflavus and Microbacterium spp. $(1.5-2.5 \mathrm{~cm})$ as a cellulolytic bacteria from the intestine of Diatraea saccharalis larvae (Dantur et al., 2015) and cellulolytic Enterobacter cloacae $(2.5 \mathrm{~cm})$
Table 2. Optical density (OD) of cell density, glucose concentration, and CMCase activity of selected lactic acid bacteria (LAB) isolated from Mentok gastrointestinal tract on $1 \%$ carboxymethilcellulose $(\mathrm{CMC})$ medium at $37^{\circ} \mathrm{C}$ for $48 \mathrm{~h}$ incubation

\begin{tabular}{cccc}
\hline LAB Isolate & $\begin{array}{c}\text { OD Value } \\
(\lambda 620 \mathrm{~nm})\end{array}$ & $\begin{array}{c}\text { Glucose } \\
\text { concentration } \\
(\mathrm{ppm})\end{array}$ & $\begin{array}{c}\text { CMCase } \\
(\mathrm{U} / \mathrm{mL})\end{array}$ \\
\hline MU 4 & $0.1744 \pm 0.005^{\mathrm{b}}$ & $44.52 \pm 3.39^{\mathrm{c}}$ & 0.008 \\
MS 14 & $0.1709 \pm 0.002^{\mathrm{b}}$ & $42.30 \pm 2.57^{\mathrm{c}}$ & 0.008 \\
MK 20 & $0.3398 \pm 0.026^{\mathrm{a}}$ & $82.67 \pm 3.34^{\mathrm{a}}$ & 0.015 \\
MK 27 & $0.2307 \pm 0.031^{\mathrm{b}}$ & $56.37 \pm 11.40^{\mathrm{b}}$ & 0.010 \\
MK 44 & $0.2944 \pm 0.063^{\mathrm{a}}$ & $76.37 \pm 8.04^{\mathrm{a}}$ & 0.014 \\
\hline
\end{tabular}

Nmte: Means in the same column with different superscript differ significantly $(\mathrm{P}<0.05)$, MK $(20,27,44)=\mathrm{LAB}$ isolated from colon; MS $14=\mathrm{LAB}$ isolated from cecum, MU $4=$ isolated from duodenum.

isolated from the rumen of Aceh cattle (Sari et al., 2017). All of the five potential LAB isolates produced higher clear zone diameters compared to those produced from cellulolytic bacterial isolated from the gut of Worker Macrotermes gilvus, i.e. 0.05 to $0,145 \mathrm{~cm}$ (Ferbiyanto et al., 2015). This result also relatively higher than cellulolytic bacteria such as Burkholderia, Bacillus, Chryseobacterium, Citrobacter, and Dyella which were isolated from different natural reserves of the subtropical region in China (Liang et al., 2014).

The other studies reported that cellulolytic bacteria isolated from horse GIT and identified as genus Lactobacilllus such as L. mucosae, L. delbrueckii, and $L$. salivarius (Al Jassim et al., 2005), Bacillus subtilis BY-2 isolated from pig intestine (Yang et al., 2014), Bacteroides succinogenes and Ruminococcus flavifaciens isolated from rat GIT (Macy et al., 1982), Klebsiella, Stenotrophomonas, Microbacterium, Bacillus and Enterococcus isolated from Diatraea saccharalis larvae (Dantur et al., 2015), cellulolytic bacteria B-6 isolated from the rumen of Buffalo (Bidura et al., 2014), and Enterobacter cloacae isolated from the rumen of Aceh cattle (Sari et al., 2017).

To identify the cell growth on liquid medium with $\mathrm{CMC}$ as a carbon source, the five selected cellulolytic LAB isolates were grown on medium containing $1 \%$ $\mathrm{CMC}$ for $48 \mathrm{~h}$ of incubation. Figure 1 illustrated that three cellulolytic LAB isolates (MK 20, MK 44 and MK 27) from colon region had the highest cell growth than MS 14 from caecum region and MU 4 from duodenum region of muscovy duck. The colon-derived LAB tend to be more adaptive in media containing cellulose substrates like CMC than those derived from the front part of the intestine. This difference was possibly related to the digestive process of feed in the colon of duck. Apajalahti (2005) stated that caecum and colon were parts of the GIT received dietary compounds that escape host digestion and absorption in the small intestine. In these regions, endogenous bacteria ferment the entering substrates. Józefiak et al. (2004) also concluded that dietary fiber (DF) consisted of a complex mixture of polymers which associated with non-carbohydrate components that was fermented in the avian GIT. The DF is predominantly found in plant cell walls and consists of NSP together with non-carbohydrate compounds in- 


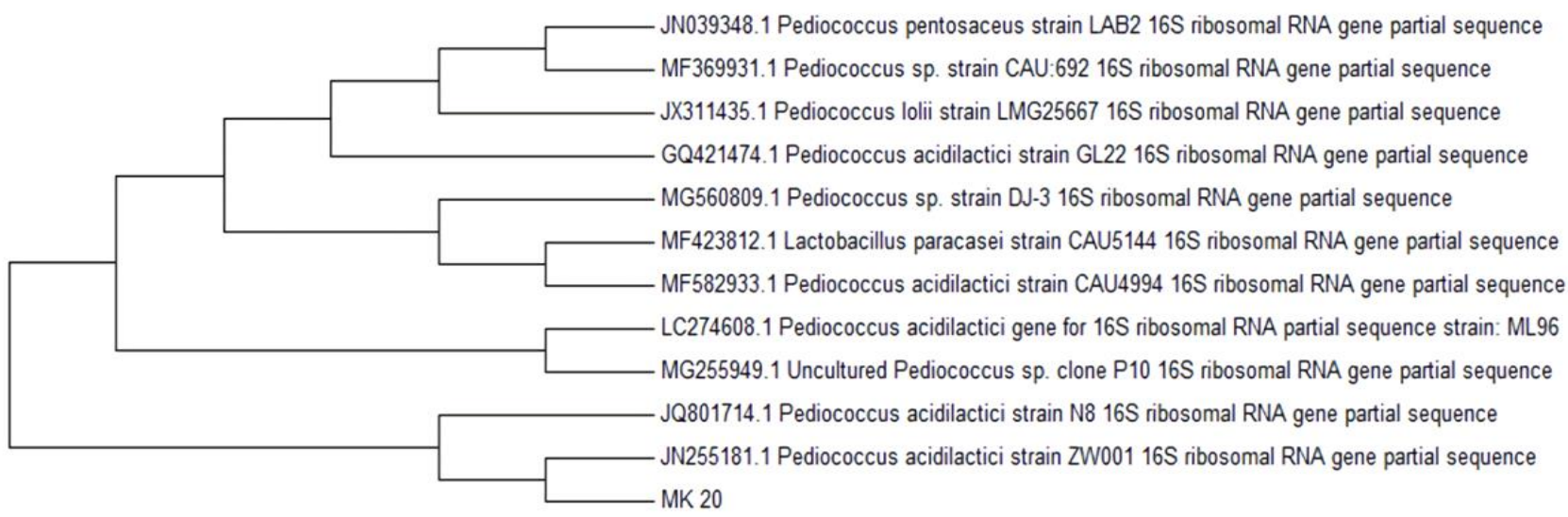

Figure 2. Phylogenetic tree of MK 20 lactic acid bacteria isolated from muscovy duck colon using the 16S rDNA gene for sequence homology studies. Sequences of reference strains obtained from DNA databases with accession numbers. Bootstrap values are based on 1,000 replicates.

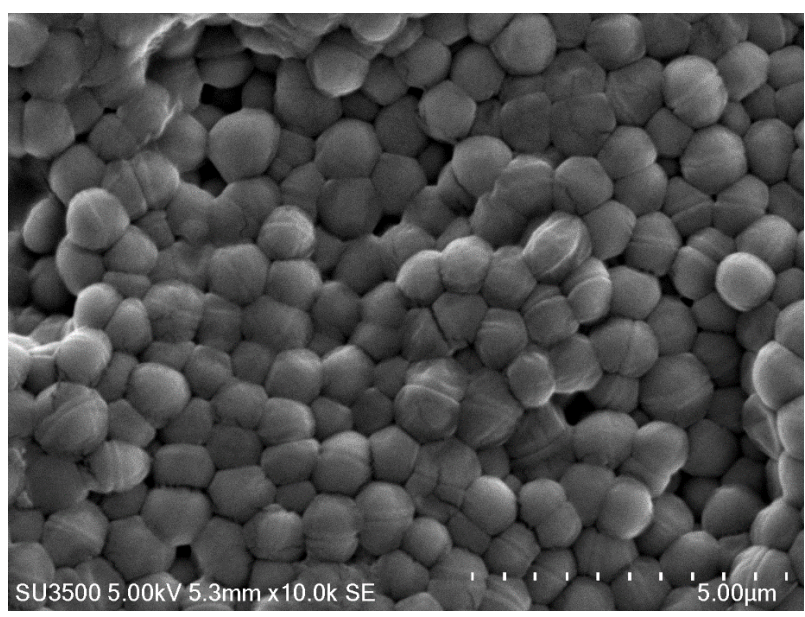

Figure 3. Scanning electron micrograph of Pediococcus acidilactici MK20 growth on MRSB medium, $37^{\circ} \mathrm{C}, 18 \mathrm{~h}$ (magnification 10,000x)

cluding lignin, protein, fatty acids, and waxes. Insoluble polysaccharides such as cellulose also fermented in avian GIT. NSP fractions have an anti-nutritive role in avian metabolism, but it was possible that some beneficial properties may be associated with the end-products of fermentation.

The five potential cellulolytic LAB were further assayed for CMCase activity in the liquid medium. The progress of carboxymethylcellulose (CMCase) was determined by measuring the release of reducing sugars from CMC (Yang et al., 2014). Screening the cellulolytic microorganism according to its cellulose degradation process could be done by Congo red, but this process could not represent the enzyme productivity by a microorganism (Liang et al., 2014).

In this study, the highest activity of CMCase in liquid medium was shown by MK 20 isolate. This result was contrary to cellulolytic assay on CMC media agar that MK 44 isolate showed the highest cellulolytic activity though both isolates were isolated from the same colon region. This result similar to those reported by Liang et al. (2014) that some strains presented large and clear hydrolyzing zones, but the activities of CMCase were undetectable in various liquid media containing CMC. This condition indicated that the concentration of the enzyme produced by the strains was difficult to be detected after cultivation in liquid medium or the ability of the strains to secrete CMCase was weak.

The highest CMCase activity from the supernatant of MK 20 isolates in this study was 0.0153 $\mathrm{U} / \mathrm{mL}$ at $48 \mathrm{~h}$ of incubation on $1 \%$ CMC substrate (Table 2). The CMCase values obtained from MK 20 was lower than the CMCase values of the cellulolytic bacteria (Streptomyces variabilis, Kocuria rosea, and Stenotrophomonas maltophilia) isolated from the Persian Gulf bay with a mean value of $0.088 \mathrm{U} / \mathrm{mL}$ (Samira et al., 2011), Paenibacillus terrae ME27-1 isolated from subtropical region in China $(0.18 \mathrm{U} / \mathrm{mL})$ (Liang et al., 2014), and Bacillus subtilis BY-2 isolated from pig's intestine (1.5 U/ $\mathrm{mL}$ ) at $24 \mathrm{~h}$ incubation (Yang et al., 2014), but higher than those of Enterococcus casseliflavus and Stenotrophomonas maltophilia $(<0.01 \mathrm{U} / \mathrm{mL})$ isolated from the intestine of Diatraea saccharalis larvae (Dantur et al., 2015).

Endo- 1,4- $\beta$-glucanase (CM-cellulase, endoglucanase, endocellulase) enzymes was known as an enzyme that breaks down the CMC substrate into sugars (Wood \& Bhat, 1988). First endo-glucanases brake cellulose into termini of cellulose chain, followed by exo-glucanases with the action to release the crystalline structure of the microfibril (Dantur et al., 2015).

The supplementation of the cellulolytic LAB as poultry probiotic was a potential strategy for increasing the digestibility of feed with cellulose content. The highest cellulolytic LAB of muscovy duck GIT in this study was identified as $P$. acidilactici MK 20 isolated from the colon region. Several studies had found genus Pediococcus LAB from the digestive tract of poultry such as $P$. acidilactici R01, and $P$. acidilactici $R 02$ were isolated from the proventriculus of broilier chicken which has resistance on bile salt and acid condition (Damayanti et al., 2014), P. pentosaceus Db9 was isolated from duodenum of broiler chicken (Damayanti et al., 2012), P. pentosaceus KT3CE27 from Thai endogenous chicken (Musikasang et al., 2009), Pediococcus from intestinal content of duck (Kurzak et al., 1998). 
P. acidilactici MK 20 from mentok GIT in this study was different from LAB species isolated from intestinal of Muscovy duck which reported in other studies such as Lactobacillus rhamnosus, Lactococcus lactis subsp lactis, L. salivarius, Streptococcus lactis, Enterococcus columbae and L. murinus from the intestine of Muscovy duck (Xie et al., 2015), Streptococcus, Enterococcus, Weissella, and Lactobacillus from intestinal content of duck (Kurzak et al., 1998), L. delbrueckii subsp. bulgaricus and $L$. reuteri $\mathrm{F} 275 \mathrm{~T}$ isolated from ducks and geese in Thailand (Kimprasit, 2013) and L. salivarius I11 from the Pengging duck's intestine (Sumarsih et al., 2014).

Pediococcus spp. are widely described as probiotics and characterized as coccus-shaped bacteria (arranged in tetrads), Gram-positive, non-motile, non-spore forming, catalase negative, and facultative anaerobes. Pediococcus strains that produce pediocin, an effective bacteriocin (Porto et al., 2017). In this study it was shown that $P$. acidilactici which was grown on MRSB medium at $37^{\circ} \mathrm{C}$ during $18 \mathrm{~h}$ arranged in single cocci or diplococci morphology (Figure 4). P. acidilactici species have Generally Regarded as Safe (GRAS) status from Food and Drug Administration of United States (FDA USA) and Qualified Presumption of Safety (QPS) status from European Food Safety Authority (EFSA) (Gaggia et al., 2010). The further research was needed to explore the potential of $P$. acidilactici MK 20 with CMCase activity as a probiotic for poultry which has beneficial properties to increase digestibility of NSP as anti-nutrient on feed.

\section{CONCLUSION}

Pediococcus acidilactici MK 20 isolated from the colon part of the gastrointestinal tract of mentok, the Indonesian muscovy duck (Anas moschata) had cellulolytic activity. Further research was needed for exploring and studying the probiotic properties of this LAB as poultry probiotic to improve feed digestibility.

\section{CONFLICT OF INTEREST}

We declare that there is no conflict of interest of the manuscript material with any financial, personal, or other relationship of other people or organization.

\section{ACKNOWLEDGEMENT}

The research was funded under The Entries List Project/DIPA 2015 of BPTBA LIPI. Authors would like to thanks to technician Madina Nurohmah, S.Pt., for supporting this research and drh. M. Faiz Karimy, M.Biotech for scanning electron microscope observation.

\section{REFERENCES}

Al Jassim, R. A. M., P.T. Scott, D. Krause, S. Denman, \& C.S. McSweeney. 2005. Cellulolytic and lactic acid bacteria in the gastrointestinal tract of the horse. Recent Advances Anim. Nutrition Australia 15

Ali, M., Sukirno, M. H. Tamzil, \& M. Ichsan. 2014. Meat traits of Muscovy ducks fed on phytonutrition meal. Int. J. Poult. Sci. 13:204-207. https://doi.org/10.3923/ijps.2014.204.207

Apajalahti, J. 2005. Comparative gut microflora, metabolic challenges, and potential opportunities. J. Appl. Poult. Res. 14:444-453. https://doi.org/10.1093/japr/14.2.444

Bedford, M. R. 2000. Exogenous enzymes in monogastric nutrition - Their current value and future benefits. Anim. Feed Sci. Technol. 86:1-13. https://doi.org/10.1016/ S0377-8401(00)00155-3

Bidura, I. G. N. G., N. W. Siti, \& I. A. P. Utami. 2014. Isolation of cellulolytic bacteria from rumen liquit of Buffalo both as a probiotics properties and has CMC-ase activity to improve nutrient quality of soybean distillery by-product as feed Int. J. Pure App. Biosci. 2:10-18.

Boros, D., R. R. Marquardt, \& W. Guenter. 1998. Site of exoenzyme action in gastrointestinal tract of broiler chicks. Can. J. Anim. Sci. 78:599-602. https://doi.org/10.4141/A97-092

Buchanan, N. P., L. B. Merritt, G. E. Seidel, \& J. S. Moritz. 2005. The effects of non-starch polysaccharide enzyme inclusion and dietary energy restriction on performance of organically-reared broiler chickens. Poult. Sci. 84:83.

Căpriță, R., A. Căpriţă, \& C. Julean. 2010. Biochemical aspects of non-starch polysaccharides. Scientific Papers Animal Science and Biotechnologies. 43:368-375.

CIVAS (Center for Indonesian VeterinaryAnalytical Studies). 2006. A Review of Free Range Duck Farming Systems in Indonesia and Assesment of Their Implication in the Spreading of the Highly Pathogenic (H5N1) Strain of Avian Influenza (HPAI). pp. 1:62.

Cobos, M. A., A. L., de Coss, N. D. Ramirez, S. S. Gonzales, \& R. F. Cerrato. 2011. Pediococcus acidilactici isolated from the rumen of lambs with rumen acidosis, 16S rRNA identify cation and sensibility to monensin and lasalocid. Res. Vet. Sci. 90: 26-30. https://doi.org/10.1016/j.rvsc.2010.05.006

Damayanti, E., H. Herdian, M. Angwar, A. Febrisiantosa, \& L. Istiqomah. 2012. Lactic acid bacterial screening from gastrointestinal digestive tract of native and broiler chicken for probiotic candidate purposes. J. Indonesian Trop. Anim. Agric. 37: 168-175. https://doi.org/10.14710/ jitaa.37.3.168-175

Damayanti, E., H. Julendra, A. Sofyan, \& S. N. Hayati. 2014 Bile salt and acid tolerant of lactic acid bacteria isolated from proventriculus of broiler chicken. Med. Pet. 37:80-86. https://doi.org/10.5398/medpet.2014.37.2.80

Dantur, K. I., R. Enrique, B. Welin, \& A. P. Castagnaro. 2015 Isolation of cellulolytic bacteria from the intestine of Diatraea saccharalis larvae and evaluation of their capacity to degrade sugarcane biomass. AMB Express 5:15. https:// doi.org/10.1186/s13568-015-0101-z

Ferbiyanto, A., I. Rusmana, \& R. Raffiudin. 2015 Characterization and identification of cellulolytic bacteria from gut of worker Macrotermes gilvus. HAYATI J. Biosci. 22. 197-200. https://doi.org/10.1016/j.hjb.2015.07.001

Fernandes, V. O., M. Costa, T. Ribeiro, L. Serrano, V. Cardoso, H. Santos, M. Lordelo, L.M.A. Ferreira, \& C.M.G.A. Fontes. 2016. 1,3-1,4--Glucanases and not 1,4--glucanases improve thenutritive value of barley-based diets for broilers. Anim. Feed Sci. Technol. 211:153-163.

Fonty, G. \& P. Gouet. 1989. Fibre-degrading microorganisms in the monogastric digestive tract. Anim. Feed Sci. Technol. 23:91-107. https://doi.org/10.1016/0377-8401(89)90092-8

Gaggia, F., P. Mattarelli, \& B. Biavati. 2010. Probiotics and prebiotics in animal feeding for safe food production. Int. J. Food Microbiol. 141:S15-S28. https://doi.org/10.1016/j. ijfoodmicro.2010.02.031

Ghose, T. K. 1987. Measurement of cellulase activities. Pure Appl. Chem. 59. https://doi.org/10.1351/pac198759020257

Gomez, K.A. \& A.A. Gomez. 1984. Stastitical procedures for agricultural research. Second edition. An international rice research institute book. John Willey and Sons Inc. New York. Toronto. 8-13; 188-207.

Gong, J., W. Si, R. J. Foster, R. Huang, H. Yu, Y. Yin, C. 
Yang, \& Y. Han. 2007. 16S rRNA gene-based analysis of mucosa associated bacterial community and phylogeny in the chicken gastrointestinal tracts: from crops to ceca. FEMS Microbiol. Ecol. 59: 147-157. https://doi. org/10.1111/j.1574-6941.2006.00193.x

Hamida, F., K. G. Wiryawan, \& A. Meryandini. 2015. Selection of lactic acid bacteria as probiotic candidate for chicken. Med. Pet. 38: 138 - 144. https://doi.org/10.5398/ medpet.2015.38.2.138

Istiqomah, L., S. N. Hayati, E. Damayanti, H. Julendra, A. A. Sakti, \& T. Untari. 2013. Performance and meat quality of broilers infected with Escherichia coli and administered with bio additive, probiotic, and antibiotic. Med. Pet. 36: 14-20. https://doi.org/10.5398/medpet.2013.36.1.14

Jannah, S., A. Dinoto, K. Wiryawan, \& I. Rusmana. 2014. Characteristics of lactic acid bacteria isolated from gastrointestinal tract of Cemani chicken and their potential use as probiotics. Med. Pet. 37:182-189. http://dx.doi.org/10.5398/ medpet.2014.37.3.182

Julendra, H., A. E. Suryani, L. Istiqomah, E. Damayanti, M. Anwar, \& N. Fitriani. 2017. Isolation of lactic acid bacteria with cholesterol-lowering activity from digestive tracts of Indonesian native chickens. Med. Pet. 40: 35-41. https:// doi.org/10.5398/medpet.2017.40.1.35

Józefiak, D., A. Rutkowski, \& S.A. Martin. 2004. Carbohydrate fermentation in the avian ceca: a review. Anim. Feed Sci. Technol. 113:1-15. https://doi.org/10.1016/j. anifeedsci.2003.09.007

Kimprasit, K. 2013. In vitro selection of potential lactic acid bacteria isolated from Ducks and Geese in Thailand. Kasetsart J. Natur. Sci. 47:261-270.

Krieg, N.R., J.T. Staley, D.R. Brown, B.P. Hedlund, B.J. Paster, N.L. Ward, W. Ludwig, \& W.B. Whitman. 2010. Bergey's Manual of Systematic Bacteriology. USA: Springer.

Kurzak, P., M. A. Ehrmann, \& R. F.Vogel. 1998. Diversity of lactic acid bacteria associated with ducks. Systematic Appl. Microbiol. 21:588-592. https://doi.org/10.1016/ S0723-2020(98)80071-4

Liang, Y. L., Z. Zhang, M. Wu, Y. Wu, \& J. X. Feng. 2014. Isolation, screening, and identification of cellulolytic bacteria from natural reserves in the subtropical region of China and optimization of cellulase production by Paenibacillus terrae ME27-1. BioMed Res. Inter. ID 512497.

Macy, J. M., R. Farrand, \& L. Montgomery. 1982. Cellulolytic and non-cellulolytic bacteria in rat gastrointestinal tracts. Appl. Environ. Microbiol. 44:1428-1434.

Meryandini, A., W. Widosari, B. Maranatha, T.C. Sunarti, N. Rachmania, \& H. Satria. 2009. Isolasi bakteri selulolitik dan karakterisasi enzimnya. Makara Sains 13: 33-38.

Musikasang, H., A. Tani, A. H-kittikun, \& S. Maneerat. 2009. Probiotic potential of lactic acid bacteria isolated from chicken gastrointestinal digestive tract. World J. Microbiol. Biotechnol. 25:1337-1345. https://doi.org/10.1007/ s11274-009-0020-8

Porto, M. C. W., T. M. Kuniyoshi, P. O. S. Azevedo, M. Vitolo, \& R. P. S. Oliveira. 2017. Pediococcus spp.: an important genus of lactic acid bacteria and pediocin producers. Biotechnol. Advances 35:361-374. https://doi.org/10.1016/j. biotechadv.2017.03.004
Promega. 2016. GoTaq ${ }^{\circledR}$ Green Master Mix Certificate of Analysis 9PIM712. http://worldwide.promega.com/resources/protocols/product-information-sheets/g/gotaq green-master-mix-m712-protocol/

Rahayu, A. G., Y. haryani, \& F. Puspita. 2014. Uji aktivitas selulolitik dari 3 Isolat bakteri Bacillus sp. Galur Lokal Riau. JOM FMIPA 1(2).

Samira, M., R. Mohammad, \& G. Gholamreza. 2011. Carboxymethyl-cellulase and filter-paperase activity of new strains isolated from Persian Gulf. Microbiol. J. 1: 8-16. https://doi.org/10.3923/mj.2011.8.16

Sari, W. N., Safika, Darmawi, \& Y. Fahrima. 2017. Isolation and identification of a cellulolytic Enterobacter from rumen of Aceh cattle. Vet. World 10:1515-1520. https://doi. org/10.14202/vetworld.2017.1515-1520

Setyati, W.A. \& Subagiyo. 2012. Isolasi dan seleksi bakteri penghasil enzim ekstraseluler (proteolitik, amiliolitik, lipolitik, dan sellulolitik), yang berasal dari sedimen kawasan Mangrove. Ilmu Kelautan 17: 164-168.

Sofyan, A., M. Angwar, H. Herdian, E. Damayanti, L. Istiqomah, A. Febrisiantosa, H. Julendra, M. H. Wibowo, \& T. Untari. 2012. Performance enhancement and immunity profile of broiler treated feed additive containing lactic acid bacteria and Ganoderma lucidum. Med. Pet. 35: 201206. https://doi.org/10.5398/medpet.2012.35.3.201

Suci, D. M., Z. Fitria, \& R. Mutia. 2017. Meat fatty acid and cholesterol content of native Indonesian Muscovy Duck fed with rice bran in traditional farm. J. Anim. Prod. 19:37-45.

Sumarsih, S., B. Sulistiyanto, C. I. Sutrisno, \& E. S. Rahayu. 2014. Characteristic of Lactobacillus isolated from Pengging Duck's intestine as probiotics. Int. J. Poultry Sci. 13:47-51. https://doi.org/10.3923/ijps.2014.47.51

Torshizi, M., A.K. Rahimi, N. Mojgani, S. Esmaeilkhanian, \& J.L. Grimes. 2008. Screening of indigenous strains of lactic acid bacteria for development of a probiotic for poultry. Asian-Aus. J. Anim. Sci. 21: 1495-1500.

Tugiyanti, E., T. Yuwanta, Zuprizal, \& Rusman. 2013. Improving performance, meat quality and muscle fiber microstructure of native Indonesian muscovy duck through feed protein and metabolizable energy. Int. J. Poult. Sci. 12:653-659. https://doi.org/10.3923/ijps.2013.653.659

Wood, T. M. and K. M. Bhat. 1988. Methods for measuring cellulose activities in Methods in Enzymology vol. 160. Academic Press. Inc.

Xie, X. L., D. P. Bai, L. N. Xie, W. N. Zhang, X. H. Huang, \& Y. F. Huang. 2015. Intestinal lactic acid bacteria from Muscovy duck as potential probiotics that alter adhesion factor gene expression. Genetics Molecular Res. 14:12262-12275. https://doi.org/10.4238/2015.October.9.15

Yang, W., F. Meng, J. Peng, P. Han, F. Fang, L. Ma, \& B. Cao. 2014. Isolation and identification of a cellulolytic bacterium from the Tibetan pig's intestine and investigation of its cellulase production. Electronic J. Biotechnol. 17:262-267. https://doi.org/10.1016/j.ejbt.2014.08.002

Yeh, R. H., C. W. Hsieh, \& K. L. Chen. 2017. Screening lactic acid bacteria to manufacture two-stage fermented feed and pelleting to investigate the feeding effect on broilers. Poult. Sci. 236-246. https://doi.org/10.3382/ps/pex300 